\title{
Self-Assembly of a Flexible Bis-Zwitterion in Polar Solution: Formation of Discrete Nanometer-Sized Cyclic Dimers
}

\author{
Carsten Schmuck, ${ }^{* 1}$ Thomas Rehm, ${ }^{1}$ Franziska Gröhn, ${ }^{2}$ Katja Klein, ${ }^{2}$ Frank Reinhold. ${ }^{2}$ \\ ${ }^{1}$ University of Würzburg, Institute of Organic Chemistry, Am Hubland, 97074 Würzburg, Germany; \\ ${ }^{2}$ Max-Planck-Institute for Polymer Research, Ackermannweg 10, 55128 Mainz, Germany
}

\section{Supporting Information}

\section{Experimental Details}

General Information: All solvents were dried and distilled under nitrogen before use. All other reagents were used as obtained from either Aldrich or Fluka. Reactions were monitored by TLC on silica gel plates (Machery-Nagel POLYGRAM SIL G/UV254). Visualization of the spots was carried out by fluorescence quenching with $254 \mathrm{~nm}$ UV light. All melting points were measured with a Büchi SMP-20 apparatus according to Dr. Tottoli with open end glas capillary tubes. The melting points are not corrected. The NMR spectra were recorded at room temperature with a Bruker AV 400 NMR spectrometer. The ${ }^{1} \mathrm{H}$ NMR spectra were recorded at $400 \mathrm{MHz}$, the ${ }^{13} \mathrm{C}$ NMR spectra at $100 \mathrm{MHz}$. The chemical shifts are relative to the signals of the used solvents: DMSO- $d_{6}\left(\delta_{1 \mathrm{H}}=2.50\right.$ and $\left.\delta_{13 \mathrm{C}}=39.52\right), \mathrm{CDCl}_{3}\left(\delta_{1 \mathrm{H}}=7.26\right.$ and $\delta_{13 \mathrm{C}}=77.16$ ). The apparent coupling constants are given in Hertz. The description of the fine structure means: $\mathrm{s}=$ singlet, br. $\mathrm{s}=$ broad singlet, $\mathrm{d}=$ doublet, $\mathrm{t}=$ triplet, $\mathrm{q}=$ quartet, $\mathrm{m}=$ multiplet, $\mathrm{dt}=$ doublet of triplets. All IR spectra were measured as $\mathrm{KBr}$ pellets on a Jasco FT-IR 410 spectrophotometer. The maxima are classified in three intensities: $\mathrm{s}$ (strong), m (middle), w (weak) and are reported in $\mathrm{cm}^{-1}$. All mass spectra were recorded with a MicroTOF focus spectromter (Bruker Daltonics).

\section{Synthesis of methyl ester 4:}

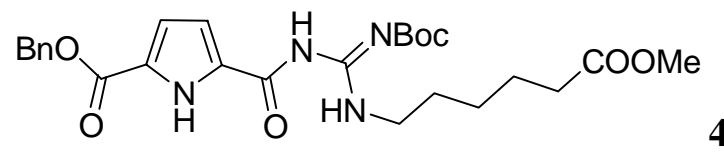

A solution of the pyrrole building block $2^{1}$ (3.54 g, $\left.9.17 \mathrm{mmol}, 1 \mathrm{eq}\right)$ in dichloromethane (80 $\mathrm{ml}$ ) was cooled to $0{ }^{\circ} \mathrm{C}$ under nitrogen atmosphere. After the addition of $\mathrm{NaH}$ (462 $\mathrm{mg}, 19.3$ mmol, $2.1 \mathrm{eq}$ ) the reaction mixture was stirred for one hour at $0{ }^{\circ} \mathrm{C}$. After that the slightly yellow solution was cooled to $-60{ }^{\circ} \mathrm{C}$ and triflic acid anhydride $(1.85 \mathrm{ml}, 11 \mathrm{mmol}, 1.2 \mathrm{eq})$ was added. The reaction mixture was stirred for three hours at $-60^{\circ} \mathrm{C}$, warmed up to room temperature within two hours and was stirred for another 24 hours. Afterwards water was

\footnotetext{
${ }^{(1)}$ Schmuck C.; Geiger L. Curr. Org. Chem. 2003, 7, 1485-1502.
} 
added dropwise under vigorous stirring until no more gas evolved. Then triethylamine (3.81 ml, $27.5 \mathrm{mmol}, 3 \mathrm{eq})$ and methyl-6-aminocaproate hydrochloride 3 (2.0 g, $11.0 \mathrm{mmol}$, $1.2 \mathrm{eq})$ were added. The orange solution was stirred for another 24 hours at room temperature. Within this time a white crystalline solid precipitated. The reaction mixture was extracted with saturated sodium hydrogen carbonate $(3 \times 120 \mathrm{ml})$ and saturated sodium chloride $(2 \mathrm{x}$ $50 \mathrm{ml}$ ). The organic phase was dried with magnesium sulphate and concentrated in vacuo. The crude product was purified by column chromatography $\left(\mathrm{SiO}_{2}\right.$, hexane/ethylacetate $=8 / 2$ $+1 \%$ triethylamine) yielding 4 as a white solid (3.4 g, $6.6 \mathrm{mmol}, 72 \%)$.

$\mathrm{mp}: 107{ }^{\circ} \mathrm{C} ; \mathrm{R}_{\mathrm{f}}=0.51\left(\mathrm{SiO}_{2}\right.$, hexane/ethylacetate $=8 / 2+1 \%$ triethylamine per $\left.100 \mathrm{ml}\right) ;{ }^{1} \mathrm{H}-$ NMR (400 MHz, $\left.\mathrm{CDCl}_{3}\right): \delta=1.40-1.44\left(\mathrm{~m}, 2 \mathrm{H}, \mathrm{CH}_{2}\right), 1.50\left(\mathrm{~s}, 9 \mathrm{H},{ }^{\mathrm{t}} \mathrm{Bu}\right), 1.64-1.71(\mathrm{~m}, 4 \mathrm{H}$, $\left.\mathrm{CH}_{2}\right), 2.34\left(\mathrm{t}, 2 \mathrm{H},{ }^{3} \mathrm{~J}=7.32 \mathrm{~Hz}, \mathrm{CH}_{2} \mathrm{COOCH}_{3}\right), 3.52\left(\mathrm{dt}, 2 \mathrm{H},{ }^{3} \mathrm{~J}_{\mathrm{CHCH}}=6.92 \mathrm{~Hz},{ }^{3} \mathrm{~J}_{\mathrm{CHNH}}=5.84\right.$ $\left.\mathrm{Hz}, \mathrm{NHCH}_{2} \mathrm{CH}_{2}\right), 3.66$ (s, 3H, $\left.\mathrm{CH}_{3}\right), 5.32$ (s, 2H, benzyl- $\left.\mathrm{CH}_{2}\right), 6.86-6.88$ (m, 1H, pyrrole$\mathrm{CH})$, 6.91-6.92 (m, 1H, pyrrole-CH), 7.32-7.44 (m, 5H, aryl-CH), $8.54\left(\mathrm{t}, 1 \mathrm{H},{ }^{3} \mathrm{~J}_{\mathrm{NHCH}}=5.04\right.$ $\mathrm{Hz}, \mathrm{NHCH}_{2} \mathrm{CH}_{2}$ ), 9.76 (br.s, $\left.1 \mathrm{H}, \mathrm{NH}\right), 12.20$ (br.s, $1 \mathrm{H}$, pyrrole-NH); ${ }^{13} \mathrm{C}-\mathrm{NMR}(100 \mathrm{MHz}$, $\left.\mathrm{CDCl}_{3}\right): \delta=24.7\left(\mathrm{CH}_{2}\right), 26.5\left(\mathrm{CH}_{2}\right), 28.2\left(\mathrm{CH}_{3},{ }^{\mathrm{t}} \mathrm{Bu},\right), 29.0\left(\mathrm{CH}_{2}\right), 34.0\left(\mathrm{CH}_{2}\right), 41.2\left(\mathrm{CH}_{2}\right)$, $51.6\left(\mathrm{CH}_{3}\right), 66.5$ (benzyl- $\left.\mathrm{CH}_{2}\right), 83.5\left(C_{\mathrm{q}},{ }^{\mathrm{t}} \mathrm{Bu}\right), 114.3$ (pyrrole- $\left.\mathrm{CH}\right), 116.3$ (pyrrole- $\left.\mathrm{CH}\right), 124.5$ $\left(C_{\mathrm{q}}\right), 128.3,128.4,128.7(\operatorname{aryl}-C H), 134.9\left(C_{\mathrm{q}}\right), 136.0\left(C_{\mathrm{q}}\right), 153.5\left(C_{\mathrm{q}}\right), 156.6\left(C_{\mathrm{q}}\right), 160.6\left(C_{\mathrm{q}}\right)$, $170.3\left(C_{\mathrm{q}}\right), 174.0\left(C_{\mathrm{q}}\right)$; FT IR $(\mathrm{KBr}) \tilde{v}\left[\mathrm{~cm}^{-1}\right]=3327[\mathrm{~s}], 3273[\mathrm{~s}], 3016[\mathrm{w}], 2987[\mathrm{w}], 2942$ [m], 2866 [w], 1730 [s], 1672 [m], 1652 [s], 1602 [m], 1534 [s], 1327 [s], 765 [s]; HR-MS (ESI pos.) $\mathrm{m} / \mathrm{z}=515.250$ (calculated for $\mathrm{C}_{26} \mathrm{H}_{34} \mathrm{~N}_{4} \mathrm{O}_{7}+\mathrm{H}^{+}$: 515.2505).

\section{Synthesis of the carboxylic acid 5}

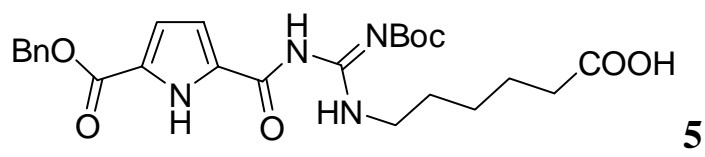

To a solution of $4(1.0 \mathrm{~g}, 1.94 \mathrm{mmol}, 1 \mathrm{eq})$ in tetrahydrofuran/water $(50 \mathrm{ml}$, v/v 4/1) lithium hydroxide monohydrate (408 mg, $9.7 \mathrm{mmol}, 5 \mathrm{eq}$ ) was added. The reaction mixture was stirred at room temperature until tlc control indicates complete conversion (hexane/ethylacetat $=8 / 2+1 \%$ triethylamine $)$. The organic solvent was evaporated and water $(10 \mathrm{ml})$ was added to the resulting solution. After acidification to a $\mathrm{pH}$ of 5 with $1 \mathrm{~N}$ hydrochloric acid the solution was extracted with ethylacetat $(3 \times 50 \mathrm{ml})$. The organic phase was dried with magnesium sulphate and concentrated in vacuo providing the free acid $\mathbf{5}$ as a white solid (964 mg, $1.97 \mathrm{mmol}, 99 \%)$. 
mp: $78{ }^{\circ} \mathrm{C} ;{ }^{1} \mathrm{H}-\mathrm{NMR}\left(400 \mathrm{MHz}, \mathrm{CDCl}_{3}\right): \delta=1.64-1.75\left(\mathrm{~m}, 6 \mathrm{H}, \mathrm{CH}_{2}\right), 1.50$ (s, 9H, $\left.{ }^{\mathrm{t}} \mathrm{Bu}\right), 2.39$ $\left(\mathrm{t}, 2 \mathrm{H},{ }^{3} \mathrm{~J}=7.32 \mathrm{~Hz} \mathrm{CH} \mathrm{COOH}_{2}, 3.54\left(\mathrm{dt}, 2 \mathrm{H},{ }^{3} \mathrm{~J}_{\mathrm{CHCH}}=6.96 \mathrm{~Hz},{ }^{3} \mathrm{~J}_{\mathrm{CHNH}}=5.92 \mathrm{~Hz}\right.\right.$, $\mathrm{NHCH}_{2} \mathrm{CH}_{2}$ ), 5.32 (s, 2H, benzyl- $\left.\mathrm{CH}_{2}\right), 6.87-6.88(\mathrm{~m}, 1 \mathrm{H}$, pyrrole- $\mathrm{CH}), 6.91-6.93(\mathrm{~m}, 1 \mathrm{H}$, pyrrole-CH) 7.33-7.43 (m, 5H, aryl-CH), $8.57\left(\mathrm{t}, 1 \mathrm{H},{ }^{3} \mathrm{~J}_{\mathrm{NHCH}}=5.52 \mathrm{~Hz}, \mathrm{NHCH}_{2} \mathrm{CH}_{2}\right), 9.2$ (br.s, 1H, NH), 12.20 (br.s, 1H, pyrrole-NH); ${ }^{13} \mathrm{C}-\mathrm{NMR}\left(100 \mathrm{MHz}, \mathrm{CDCl}_{3}\right): \delta=24.2\left(\mathrm{CH}_{2}\right)$, $26.5\left(\mathrm{CH}_{2}\right), 28.2\left(\mathrm{CH}_{3},{ }^{\mathrm{t}} \mathrm{Bu}\right), 28.9\left(\mathrm{CH}_{2}\right), 33.6\left(\mathrm{CH}_{2}\right), 41.2\left(\mathrm{CH}_{2}\right), 66.6$ (benzyl- $\left.\mathrm{CH}_{2}\right), 83.6\left(C_{\mathrm{q}}\right.$, $\left.{ }^{\mathrm{t}} \mathrm{Bu}\right), 114.4$ (pyrrole- $\left.C \mathrm{H}\right), 116.5$ (pyrrole- $\left.C \mathrm{H}\right), 124.5\left(C_{\mathrm{q}}\right), 128.4,128.5,128.8$ (aryl- $\left.C \mathrm{H}\right)$, $135.6\left(C_{\mathrm{q}}\right), 136.0\left(C_{\mathrm{q}}\right), 153.5\left(C_{\mathrm{q}}\right), 156.7\left(C_{\mathrm{q}}\right), 161.0\left(C_{\mathrm{q}}\right), 170.4\left(C_{\mathrm{q}}\right), 178.2\left(C_{\mathrm{q}}\right)$; FT IR $(\mathrm{KBr})$ $\widetilde{V}\left[\mathrm{~cm}^{-1}\right]=3309[\mathrm{~s}], 3039[\mathrm{w}], 2977[\mathrm{w}], 2938[\mathrm{~m}], 2865[\mathrm{w}], 1724$ [s], 1607 [s], 1623 [s], 1589 [s], 1543 [m], 1281 [s], 772 [w]; HR-MS (ESI pos.) m/z = 523.216 (calculated for $\mathrm{C}_{25} \mathrm{H}_{31} \mathrm{~N}_{4} \mathrm{O}_{7}+\mathrm{Na}^{+}:$523.2169).

\section{Synthesis of the protected bis-zwitterion 7}

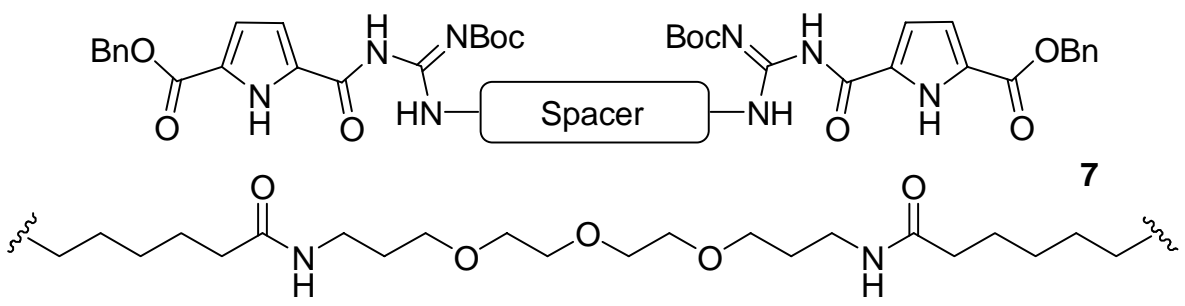

A solution of 5 (1.00 g, $1.99 \mathrm{mmol}, 2 \mathrm{eq})$ and PyBOP (1.14 g, $2.19 \mathrm{mmol}, 2.2 \mathrm{eq})$ was stirred in DMF (40 ml) and $\mathrm{N}$-Methylmorpholine $(4 \mathrm{ml})$ for one hour at room temperature. After the addition of 1,13-diamino-4, 7, 10-trioxatridecan $6(240 \mu \mathrm{l}, 1.00 \mathrm{mmol}, 1 \mathrm{eq})$ the reaction mixture was stirred for 24 hours at room temperature. The slightly yellow solution was poured into water $(50 \mathrm{ml})$, extracted with diethylether $(4 \mathrm{x} 90 \mathrm{ml})$ and washed with concentrated solution of sodium chloride $(2 \times 50 \mathrm{ml})$. The organic phase was dried with magnesium sulphate and concentrated in vacuo. The crude product was purified by column chromatography $\left(\mathrm{SiO}_{2}\right.$, ethylacetate/methanol $\left.=8 / 1\right)$. For further purification the resulting oil was lyophilised from water/methanol (v/v, 9/1) yielding 7 as a white solid (460 mg, 0.39 mmol, $39 \%)$.

mp: $60{ }^{\circ} \mathrm{C} ; \mathrm{R}_{\mathrm{f}}=0.55\left(\mathrm{SiO}_{2}\right.$, ethylacetate/methanol = 8/1); ${ }^{1} \mathrm{H}-\mathrm{NMR}\left(400 \mathrm{MHz}, \mathrm{CDCl}_{3}\right): \delta=$ $1.50\left(\mathrm{~s}, 18 \mathrm{H},{ }^{\mathrm{t}} \mathrm{Bu}\right), 1.64-1.77\left(\mathrm{~m}, 16 \mathrm{H}, \mathrm{CH}_{2}\right), 2.17$ (t, 4H, ${ }^{3} \mathrm{~J}=7.32 \mathrm{~Hz} \mathrm{CH} \mathrm{CONH}_{2}, 3.33$ (dt, $\left.4 \mathrm{H},{ }^{3} \mathrm{~J}_{\mathrm{CHCH}}=6.32 \mathrm{~Hz},{ }^{3} \mathrm{~J}_{\mathrm{CHNH}}=5.96 \mathrm{~Hz}, \mathrm{NHCH}_{2} \mathrm{CH}_{2}\right), 3.51-3.53\left(\mathrm{~m}, 8 \mathrm{H}, \mathrm{CH}_{2}\right), 3.55-3.57(\mathrm{~m}$, $4 \mathrm{H}, \mathrm{CH}_{2}$ ), 3.60-3.62 (m, 4H, $\mathrm{CH}_{2}$ ), 5.31 (s, 4H, benzyl- $\mathrm{CH}_{2}$ ), 6.14 (br.s, $2 \mathrm{H}, \mathrm{CONHCH}_{2}$ ) 
6.86-6.88 (m, 2H, pyrrole- $\mathrm{CH}), 6.90-6.92(\mathrm{~m}, 2 \mathrm{H}$, pyrrole- $\mathrm{CH})$ 7.33-7.43 (m, 10H, aryl-CH), 8.54 (br.s, $2 \mathrm{H}, \mathrm{NHCH}_{2} \mathrm{CH}_{2}$ ), 9.78 (br.s, $2 \mathrm{H}, \mathrm{NH}$ ), 12.18 (br.s, $2 \mathrm{H}$, pyrrole-NH); ${ }^{3} \mathrm{C}-\mathrm{NMR}$ $\left(100 \mathrm{MHz},\left[\mathrm{d}_{6}\right] \mathrm{DMSO}\right): \delta=25.5\left(\mathrm{CH}_{2}\right), 26.8\left(\mathrm{CH}_{2}\right), 28.2\left(\mathrm{CH}_{3},{ }^{\mathrm{t}} \mathrm{Bu}\right), 29.2\left(\mathrm{CH}_{2}\right), 29.3\left(\mathrm{CH}_{2}\right)$, $36.6\left(\mathrm{CH}_{2}\right), 37.9\left(\mathrm{CH}_{2}\right), 41.3\left(\mathrm{CH}_{2}\right), 66.5$ (benzyl- $\left.\mathrm{CH}_{2}\right), 70.0\left(\mathrm{CH}_{2}\right), 70.2\left(\mathrm{CH}_{2}\right), 70.6\left(\mathrm{CH}_{2}\right)$, $83.6\left(C_{\mathrm{q}},{ }^{\mathrm{t}} \mathrm{Bu}\right), 114.3$ (pyrrole- $\left.C \mathrm{H}\right), 116.3$ (pyrrole- $\left.C \mathrm{H}\right), 124.5\left(C_{\mathrm{q}}\right), 128.3,128.5,128.8$ (aryl$C \mathrm{H}), 135.0\left(C_{\mathrm{q}}\right), 136.0\left(C_{\mathrm{q}}\right), 153.4\left(C_{\mathrm{q}}\right), 156.6\left(C_{\mathrm{q}}\right), 160.7\left(C_{\mathrm{q}}\right), 170.3\left(C_{\mathrm{q}}\right), 172.9\left(C_{\mathrm{q}}\right)$; FT IR $(\mathrm{KBr}) \tilde{V}\left[\mathrm{~cm}^{-1}\right]=3316[\mathrm{w}], 3246[\mathrm{w}], 3030[\mathrm{w}], 2980[\mathrm{~m}], 2940[\mathrm{~m}], 2878[\mathrm{w}], 1717[\mathrm{~s}]$, 1655 [s], 1624 [s], 1255 [s], 786 [m]; HR-MS (ESI pos.) m/z = 1207.6036 (calculated for $\mathrm{C}_{60} \mathrm{H}_{84} \mathrm{~N}_{10} \mathrm{O}_{15}+\mathrm{Na}^{+}:$1207.6014).

\section{Synthesis of the bis-zwitterion 1}
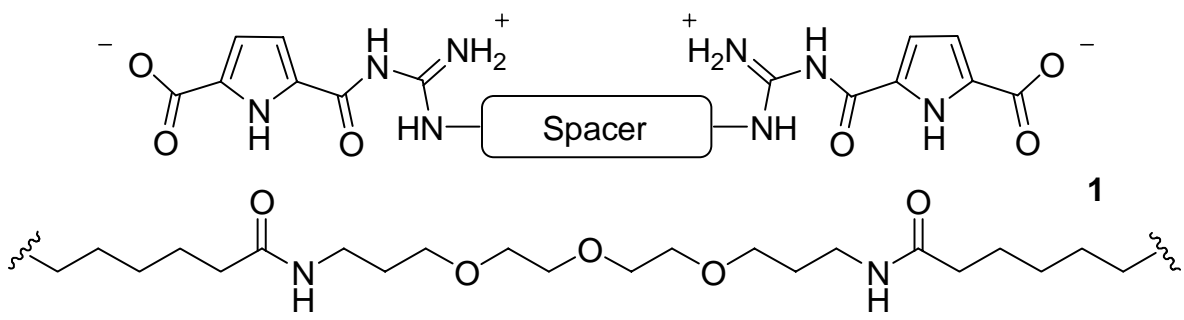

A mixture of 7 (320 mg, $0.27 \mathrm{mmol}, 1 \mathrm{eq})$ and palladium on activated charcoal $(32 \mathrm{mg})$ in tetrahydrofuran $(40 \mathrm{ml})$ was stirred for four hours under hydrogen atmosphere. The reaction was controlled via tlc (ethylacetat/methanol $=8 / 1+1 \%$ triethylamine). After complete conversion the mixture was filtered over a celite pad and washed several times with ethylacetate. The solvent was evaporated and the resulting oil was dried in high vacuum. After the addition of trifluoracetic acid $(3 \mathrm{ml})$ the reaction mixture was stirred for two hours at room temperature. After that the remaining trifluoracetic acid was removed in high vacuum. The resulting oil was dissolved in water and $0.5 \mathrm{~N}$ sodium hydroxide was added until a white solid precipitated ( $\mathrm{pH} \sim 5$ to 6 ). The crude product was filtered, washed several times with water and lyophilised from water resulting 1 as a white powder (172 mg, $0.21 \mathrm{mmol}, 89 \%)$. For further purification 1 (100 mg) was diluted in water/dioxan $(40 \mathrm{ml}, 1 / 1, \mathrm{v} / \mathrm{v})$ and refluxed for one hour. The slightly white suspension was filtered and washed several times with pure water and diethylether. The resulting white solid $(80 \mathrm{mg})$ was dried in high vacuum.

For analytic purposes the picrate salt of $\mathbf{1}$ was produced by addition of aqueous picric acid to pure 1. The suspension was refluxed until a clear deep yellow solution resulted. The picrate 
salt crystallized within 3 hours of cooling down to room temperature. Spectral data below are given for the picrate salt.

mp: $223{ }^{\circ} \mathrm{C} ;{ }^{1} \mathrm{H}-\mathrm{NMR}\left(400 \mathrm{MHz},\left[\mathrm{d}_{6}\right] \mathrm{DMSO}\right): \delta=1.26-1.33\left(\mathrm{~m}, 4 \mathrm{H}, \mathrm{CH}_{2}\right), 1.48-1.63(\mathrm{~m}$, $\left.12 \mathrm{H}, \mathrm{CH}_{2}\right), 2.06\left(\mathrm{t}, 4 \mathrm{H},{ }^{3} \mathrm{~J}=7.32 \mathrm{~Hz} \mathrm{CH} \mathrm{CONH}_{2}, 3.06\left(\mathrm{dt}, 4 \mathrm{H},{ }^{3} \mathrm{~J}_{\mathrm{CHCH}}=6.80 \mathrm{~Hz},{ }^{3} \mathrm{~J}_{\mathrm{CHNH}}=\right.\right.$ $6.08 \mathrm{~Hz}, \mathrm{NHCH}_{2} \mathrm{CH}_{2}$ ), 3.28-3.41 (m, 8H, $\mathrm{CH}_{2}$ ), 3.44-3.51 (m, 8H, CH $), 6.85$ (br.s, 2H, pyrrole-CH), 7.00-7.02 (m, 2H, pyrrole- $\mathrm{CH}), 7.74\left(\mathrm{t}, 2 \mathrm{H},{ }^{3} \mathrm{~J}_{\mathrm{NHCH}}=5.4 \mathrm{~Hz}, \mathrm{CONHCH}_{2}\right), 8.58$ (s, 4H, picrate-CH), 8.77 (br.s., 2H, $\mathrm{NHCH}_{2}$ ), 10.76 (br.s, 2H, $\mathrm{NH}$ ), 12.68 (br.s, 2H, pyrrole$\mathrm{NH}), 13.12$ (br.s, $2 \mathrm{H}, \mathrm{COOH}$ ); The guanidinio-NHs $(4 \mathrm{H})$ are superposed by picrate-CHs and amide-NHs. ${ }^{13} \mathrm{C}-\mathrm{NMR}\left(100 \mathrm{MHz},\left[\mathrm{d}_{6}\right] \mathrm{DMSO}\right): \delta=24.8\left(\mathrm{CH}_{2}\right), 25.6\left(\mathrm{CH}_{2}\right), 27.6\left(\mathrm{CH}_{2}\right), 29.4$ $\left(\mathrm{CH}_{2}\right), 35.2\left(\mathrm{CH}_{2}\right), 35.7\left(\mathrm{CH}_{2}\right), 41.1\left(\mathrm{CH}_{2}\right), 68.1\left(\mathrm{CH}_{2}\right), 69.5\left(\mathrm{CH}_{2}\right), 69.7\left(\mathrm{CH}_{2}\right), 115.2$ (pyrrole- $C \mathrm{H}), 115.5$ (pyrrole- $C \mathrm{H}), 124.1\left(C_{\mathrm{q}}\right), 125.1$ (picrate- $\left.C \mathrm{H}\right), 127.0\left(C_{\mathrm{q}}\right), 129.3\left(C_{\mathrm{q}}\right)$, $141.8\left(C_{\mathrm{q}}\right), 153.0\left(C_{\mathrm{q}}\right), 159.2\left(C_{\mathrm{q}}\right), 160.8\left(C_{\mathrm{q}}\right), 161.2\left(C_{\mathrm{q}}\right), 171.8\left(C_{\mathrm{q}}\right)$; FT IR $(\mathrm{KBr}) \widetilde{v}\left[\mathrm{~cm}^{-1}\right]=$ 3270 [m], 3190 [s], 3097 [w], 2937 [m], 2868 [m], 1719 [s], 1647 [s], 1556 [m], 1489 [m], 1448 [m], 1352 [s], 1321 [s]; HR-MS (ESI pos.) m/z = 805.4219 (calculated for $\mathrm{C}_{36} \mathrm{H}_{56} \mathrm{~N}_{10} \mathrm{O}_{11}$ $+\mathrm{H}^{+}:$805.4207).

\section{NMR Dilution studies:}

Solutions of 1 with varying concentrations (from 0.5 to $50 \mathrm{mM}$ ) were obtained by diluting aliquots of concentrated stock solutions in DMSO- $d_{6}$ to a total volume of $600 \mu \mathrm{l}$. The chemical shifts were recorded for each sample relative to the deuterated solvent.

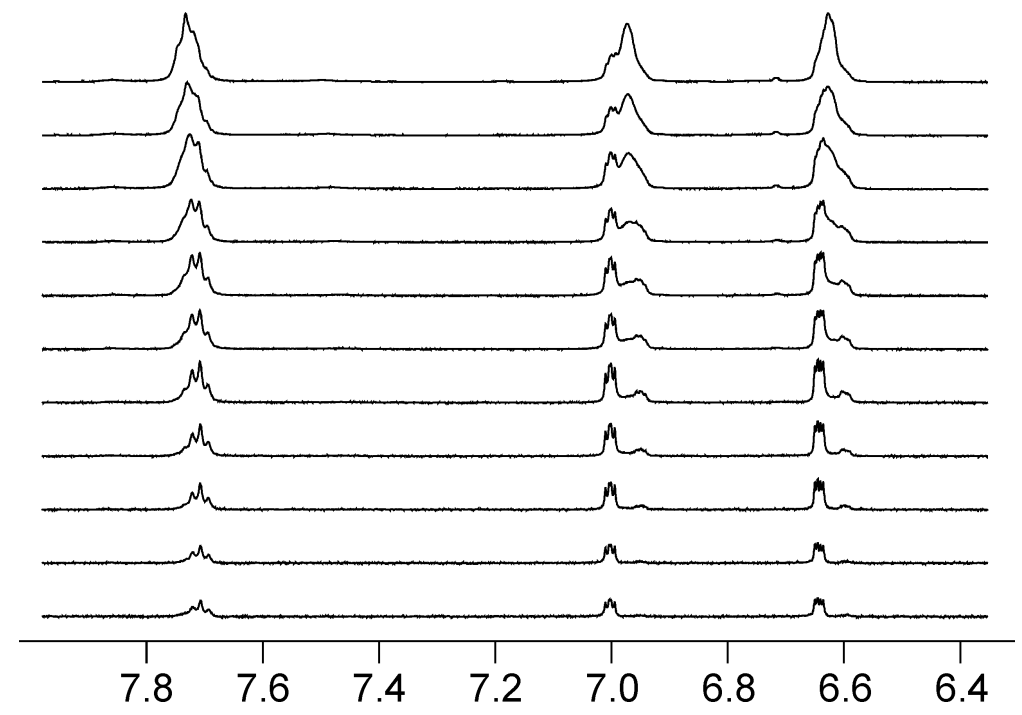

Figure S1. Part of the $1 \mathrm{H}-\mathrm{nmr}$ spectrum of 1 upon varying concentrations $(0.5$ to $50 \mathrm{mM}$ from bottom to top). 


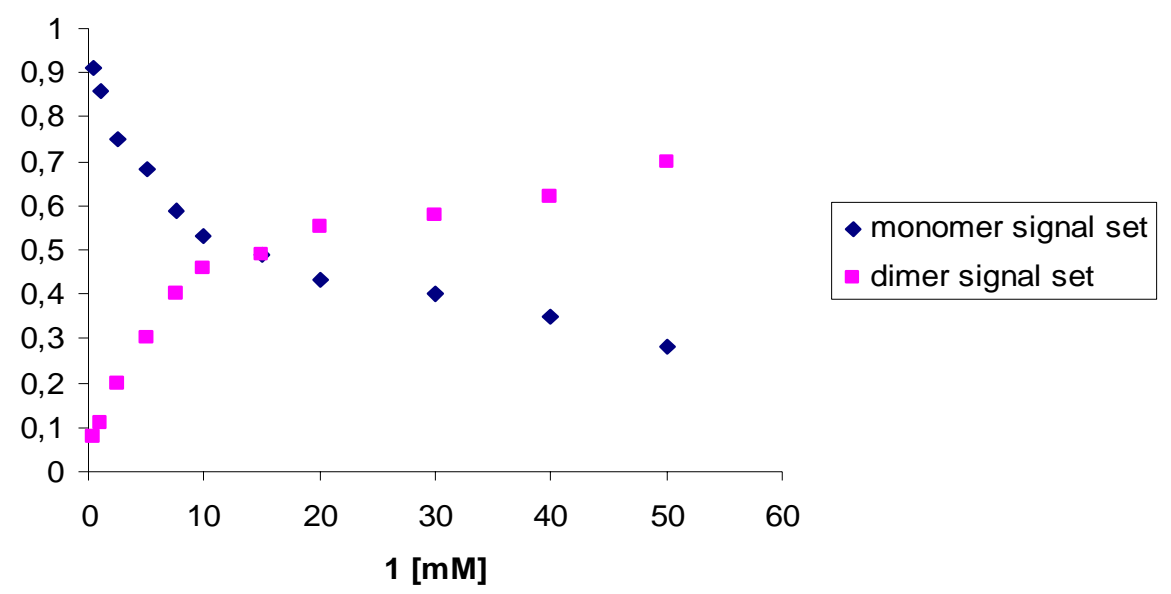

Figure S2. Intensity of the pyrrole-NH nmr signal of $\mathbf{1}$ for both signal sets with varying concentration.

\section{DOSY NMR experiments:}

Solutions of 1 (1 and $30 \mathrm{mM})$ and $7(4 \mathrm{mM})$ were obtained by diluting aliquots of concentrated stock solutions in DMSO- $d_{6}$ to a total volume of $600 \mu$ l. TMS was used as internal reference. For each sample the chemical shifts and diffusion coefficients were recorded on a Bruker DMX 600 spectrometer equipped with a gradient unit and a conventional $5 \mathrm{~mm}$ broadband $\left({ }^{15} \mathrm{~N}-{ }^{31} \mathrm{P}\right) /{ }^{1} \mathrm{H}$ probe with automatic tune/match accessory and $\mathrm{z}$ axis gradient coil capable of producing pulsed magnetic field gradients in $\mathrm{z}$ direction of $52 \mathrm{G}$ $\mathrm{cm}^{-1}$. The longitudinal eddy current delay sequence with bipolar gradient pulse pairs for diffusion (BPP-LED) ${ }^{2}$ and additional sinusoidal spoil gradients after the second and fourth $90^{\circ}$ pulses was used with the following acquisition parameters: duration $\delta$ of a bipolar gradient pulse: between $5.0 \mathrm{~ms}$ and $8.0 \mathrm{~ms}$, diffusion time $\Delta: 50 \mathrm{~ms}$, spoiler gradient duration: $5.0 \mathrm{~ms}$, spoiler gradient strengths: 17.13 and $13.17 \%$ of maximum gradient strength in 32 linear steps. Signal averaging from 16 to 288 scans per increment as required for adequate signal-to-noise ratio. Data were acquired and processed using the software XWIN-NMR 3.5, patch level 6.

\footnotetext{
${ }^{(2)}$ Wu, D.; Chen, A.; Johnson, C. S. Jr. J. Magn. Reson. A 1995, 115, 260-264.
} 
$1(1 \mathrm{mM}, T=299.9 \mathrm{~K})$

\begin{tabular}{c|cc}
$\delta[\mathrm{ppm}]$ & $D \cdot 10^{-10}\left[\mathrm{~m}^{2} / \mathrm{s}\right]$ & \\
\cline { 1 - 2 } 7,725 & 1,479 & \\
7,003 & 1,502 & \\
6,643 & 1,496 & \\
3,319 & 8,691 & $\mathrm{H}_{2} \mathrm{O}$ \\
3,209 & 1,570 & \\
2,991 & 1,541 & \\
2,501 & 6,719 & DMSO \\
2,053 & 1,477 & \\
1,501 & 1,508 & \\
1,302 & 1,491 &
\end{tabular}

$1(30 \mathrm{mM}, T=299.0 \mathrm{~K})$

\begin{tabular}{c|cc}
$\delta[\mathrm{ppm}]$ & $D \cdot 10^{-11}\left[\mathrm{~m}^{2} / \mathrm{s}\right]$ & \\
\cline { 1 - 2 } 7,749 & 5,502 & \\
6,982 & 4,809 & \\
6,636 & 4,751 & \\
3,476 & 5,020 & \\
3,438 & 5,000 & \\
3,314 & 5,814 & \\
3,338 & $7,459 \cdot 10^{-10}$ & $\mathrm{H}_{2} \mathrm{O}$ \\
3,071 & 5,333 & \\
2,511 & $6,170 \cdot 10^{-10}$ & DMSO \\
2,071 & 5,820 & \\
1,605 & 5,943 & \\
1,542 & 5,994 & \\
1,315 & 6,606 & \\
0,007 & $5,418 \cdot 10^{-10}$ & TMS
\end{tabular}

$7(4 \mathrm{mM}, T=299.6 \mathrm{~K})$

\begin{tabular}{c|cc}
$\delta[\mathrm{ppm}]$ & $D \cdot 10^{-11}\left[\mathrm{~m}^{2} / \mathrm{s}\right]$ & \\
\cline { 1 - 2 } 8,909 & $-9,96$ & \\
8,547 & $-9,976$ & \\
7,734 & $-9,974$ & \\
6,744 & $-9,969$ & \\
6,644 & $-9,93$ & \\
3,493 & $-9,979$ & \\
3,06 & $-9,991$ & \\
2,506 & $-9,193$ & DMSO \\
2,051 & $-9,985$ & \\
1,589 & $-9,978$ & \\
1,491 & $-9,968$ & \\
0,002 & $-9,215$ & TMS
\end{tabular}


At high concentrations both monomer and dimer exist in solution. Because of this no clear signal assignment could be done for some of the $\mathrm{CH}_{2}$ protons.

For the calculation of the hydrodynamic radii $r_{H}$ the diffusion coefficients $D$ averaged over all observable non-exchanging $\mathrm{nmr}$ signals for each species were used.

$$
r_{H}=\frac{k \cdot T}{6 \pi \cdot \eta \cdot D}(\text { Stokes-Einstein equation })^{3}
$$

with:

$k=1.38066 \cdot 10^{-23} \mathrm{~N} \cdot \mathrm{m} / \mathrm{K}^{4}$

$\eta_{\text {DMSO }}=1.987 \cdot 10^{-3} \mathrm{~N} \cdot \mathrm{s} / \mathrm{m}^{24}$

\begin{tabular}{l|l|l} 
& $\varnothing D\left[\mathrm{~m}^{2} / \mathrm{s}\right]$ & $r_{H} \cdot 10^{-9}[\mathrm{~m}]$ \\
\hline $\mathbf{1}(1 \mathrm{mM})$ & $1,508 \cdot 10^{-10}$ & 0,73 \\
$\mathbf{1}(30 \mathrm{mM})$ & $5,510 \cdot 10^{-11}$ & 2,00 \\
$\mathbf{7}(4 \mathrm{mM})$ & $1,069 \cdot 10^{-10}$ & 1,03
\end{tabular}

\section{ESI-MS}

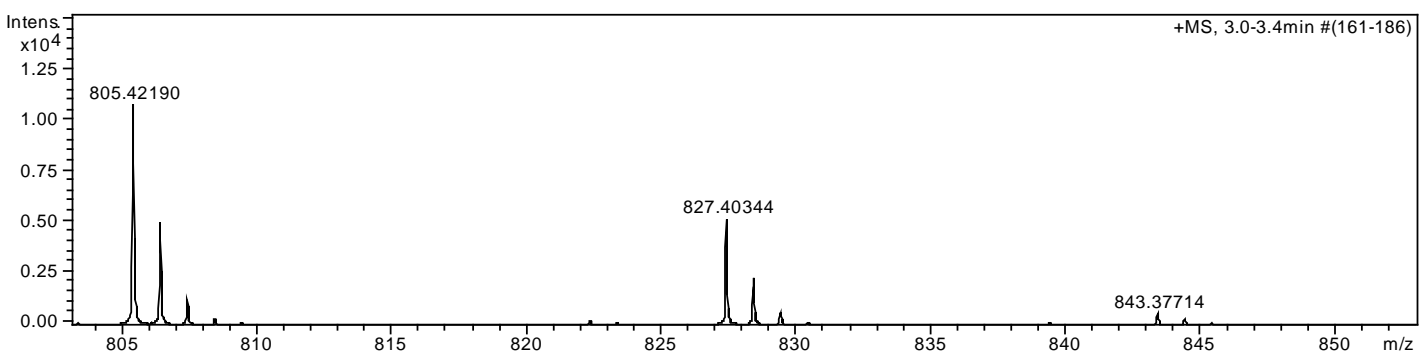

Figure S3. HR-MS (ESI pos.) spectrum of the protonated monomer, the sodium and the potassium adduct.

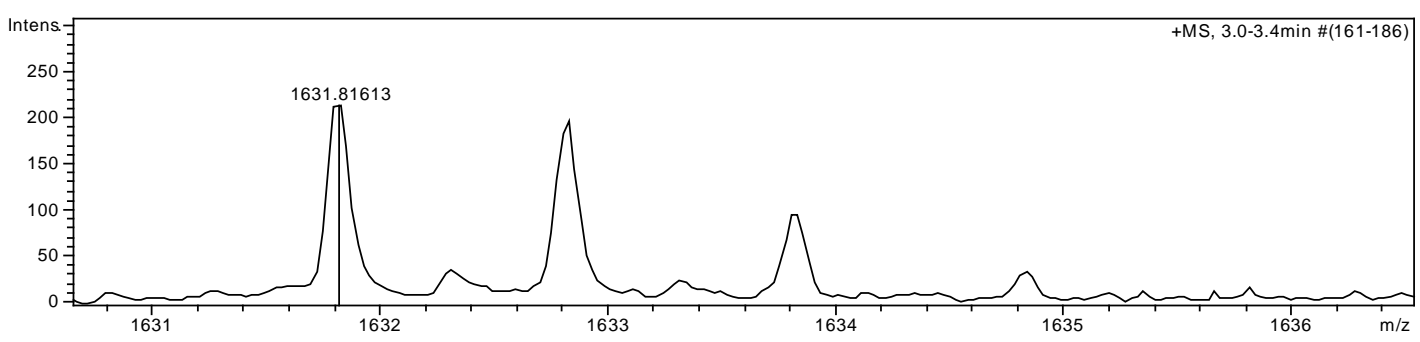

Figure S4. HR-MS (ESI pos.) spectrum of the sodium adduct of the dimer.

\footnotetext{
${ }^{(3)}$ Elias, H.-G. Polymere: Von Monomeren und Makromolekülen zu Werkstoffen Hüthig \& Wepf Verlag: Zug, Heidelberg, Oxford, CT/USA 1996.

${ }^{(4)}$ Lide, D. R. CRC Handbook of Chemistry and Physics 1995-1996, $76^{\text {th }}$ Edition CRC Press: Boca Raton, New York, London, Tokyo 1996.
} 


\section{Molecular Modelling:}

Molecular mechanics calculations were performed using the Macromodel V 8.0 software package. The implemented amber* force field was used with GB/SA water solvation treatment. For both monomer and dimer first a Monte Carlo conformational search with 100.000 steps was performed until the minimum structure was found several times. The resulting energy minimized structures (the monomer is shown below, the dimer is shown in the manuscript) were then further subjected to a MD simulation $(300 \mathrm{~K}, 500 \mathrm{ps})$ to probe their conformational stability.

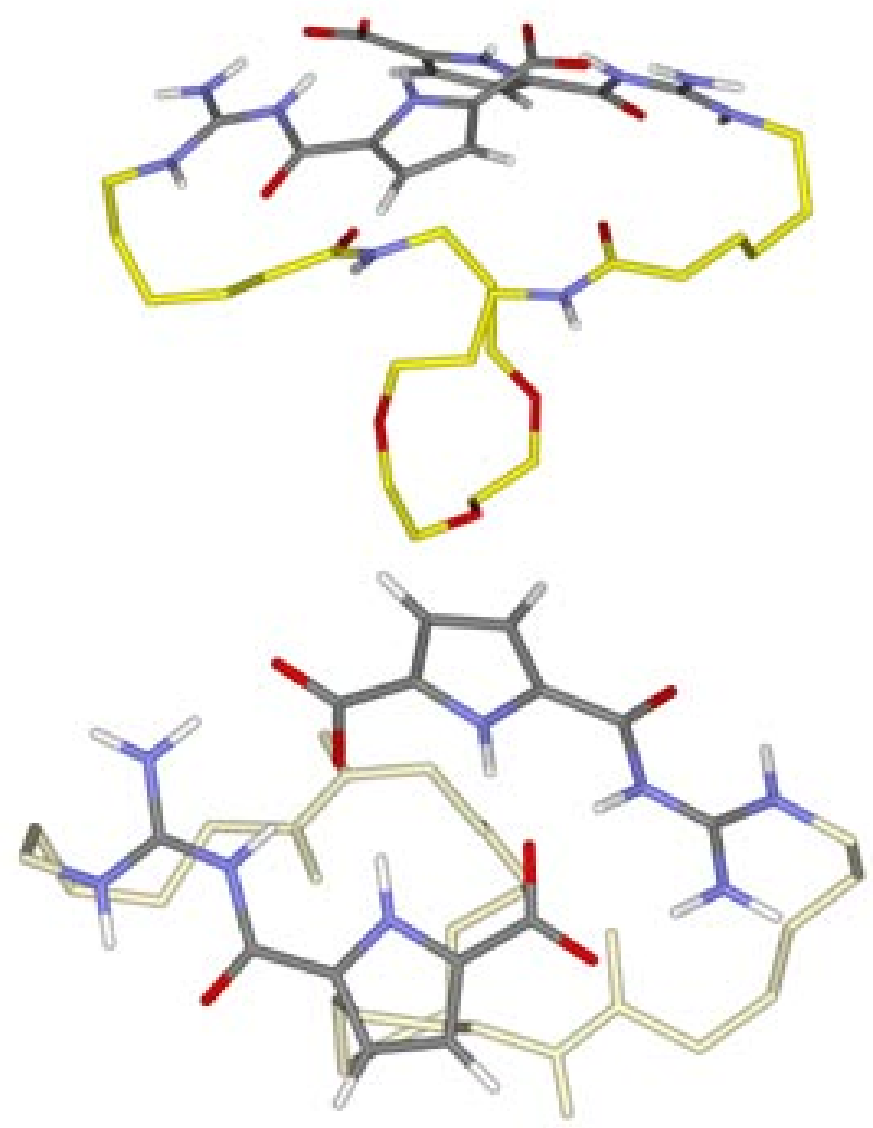

Figure S5. Calculated structure of monomeric 1. Side view (top) and top view (bottom). The linker is shown in yellow, the zwitterions in grey. Non-polar hydrogens omitted for clarity. 


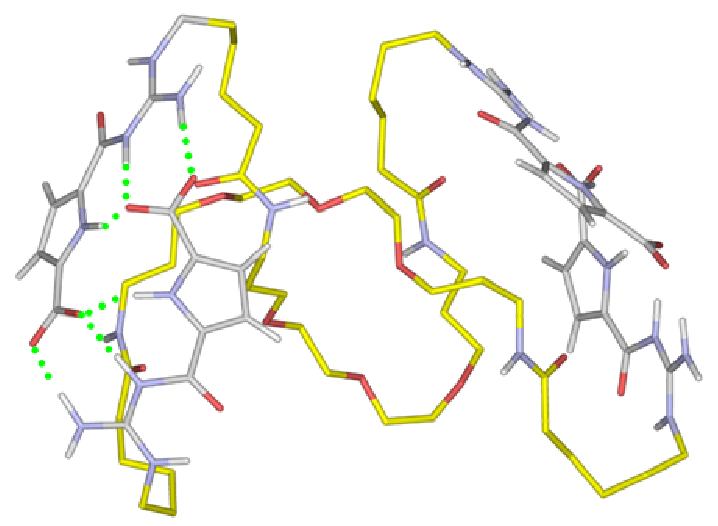

Figure S6. calculated structure of the cyclic dimer (bottom). The linker is shown in yellow, the interacting zwitterions in grey. At the left side the H-bonding pattern is highlighted in green [non-polar hydrogens omitted for clarity].

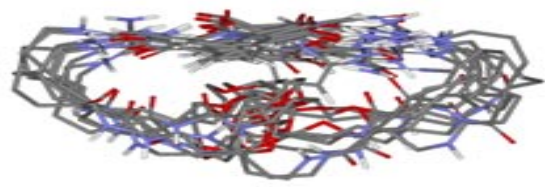

monomeric 1

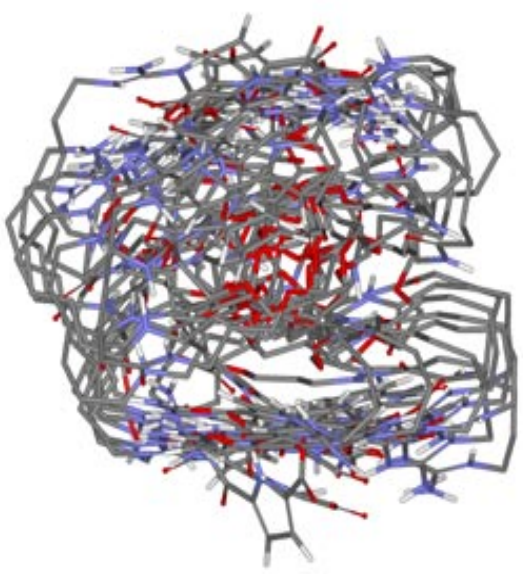

dimeric 1

Figure S7. Structural stability of monomeric and dimeric $\mathbf{1}$ as obtained from a MD simulation (500 ps at $300 \mathrm{~K}$; snapshot taken every $50 \mathrm{ps}$ ). While the monomer (left) has a rather well defined structure, the cyclic dimer (right) is still flexible but on average represents a spherical particle.

\section{Dynamic light scattering}

Light scattering measurements were performed with a setup for combined static and dynamic light scattering consisting of an ALV/SP-86 goniometer and an ALV-5000/E multitau correlator. A He-Ne laser operating at a wavelength of $647.1 \mathrm{~nm}$ and a maximum output power of $100 \mathrm{~mW}$ was used as light source. A concentration range of $25 \mathrm{mM}$ to $50 \mathrm{mM}$ in DMSO was investigated. The solutions were transferred by filtering through a Millipore 0.45 $\mu \mathrm{m}$ pore size teflon filter into $1 \mathrm{~cm}$ diameter dust free quartz cells. Measurements were performed at scattering angles of $30^{\circ}$ to $150^{\circ}$. The volume corrected scattering intensity of the 
toluene standard lies within $\pm 2 \%$ statistical error. The time autocorrelation function of the scattered intensity was measured (homodyne mode) and converted to the scattered electric field autocorrelation function via Siegert relation. The electric field autocorrelation function is analyzed via Inverse Laplace Transformation using the program CONTIN by S.Provencher. The apparent diffusion coefficient was calculated from the inverse relaxation time via Landau-Plazcek relationship and plotted versus scattering vector. No expressed angular dependence is observed and apparent diffusion coefficients lie within $\pm 2 \%$ of the average value. The hydrodynamic radius cited in the manuscript is obtained via Stokes-Einstein relation from the averaged diffusion coefficients. The distribution as function of hydrodynamic radii rather than relaxation times or relaxation rates in Figure 2 is given for $90^{\circ}$ scattering angle to demonstrate the size distribution more obviously.

\section{Small angle neutron scattering (SANS)}

Samples for SANS measurements were transferred into optical quality quartz cells with $2 \mathrm{~mm}$ path length. SANS studies were performed at the Institute Laue Langevin (ILL), Grenoble, France. Measurements were made using the D11 SANS instrument with a neutron wavelength $\lambda=0.6 \mathrm{~nm}$ and wavelength spread of $\Delta \lambda / \lambda=0.11$. Sample detector distances used were $26 \mathrm{~m}, 5.4 \mathrm{~m}$ and $1.2 \mathrm{~m}$. A concentration range of $22 \mathrm{mM}$ to $45 \mathrm{mM}$ in DMSO was investigated. For most of the q-range of the $26 \mathrm{~m}$ detector distance, no scattering intensity sufficiently above the solvent scattering was detected so that data used for analysis mainly result from the two shorter sample- detector distances and thereby a scattering vector range of $0.127 \mathrm{~nm}^{-1}$ to $3.17 \mathrm{~nm}^{-1}$ was covered. Data were corrected for empty quartz cell scattering, electronic background and detector uniformity, and converted to an absolute scale using secondary standards. The data were further corrected by subtracting the contributions from solvent scattering and incoherent background.

According to the pair distance distribution function $\mathrm{P}(\mathrm{r})$ calculated from the SANS data over the whole measured range of scattering vectors a very small amount of larger particles with a maximum diameter up to $11 \mathrm{~nm}$ is also present in the solution in addition to monomers and dimers. This is in accordance with the width of the distribution of hydrodynamic radii in Figure 2 and might be due to the formation of higher oligomers. However, the amount of these larger aggregates is within the resolution range of DLS and SANS and can therefore not be resolved and quantified exactly. 